\title{
Research on the Factors Affecting the Total Factor Productivity of Chinese Life Insurance Companies
}

\author{
Zhe Sun \\ Central University of Finance and Economics, Insurance School \\ Beijing 102206, China
}

\begin{abstract}
Based on the latest method of total factor productivity research at home and abroad, this paper uses the panel data of 17 Chinese life insurance companies from 2007 to 2016 to estimate the total factor productivity of Chinese insurance companies using the Malmquist index analysis method of DEA model. The measurement method is a regression analysis of several factors affecting the total factor productivity of Chinese insurance companies. The empirical results show that among the micro factors, the asset-liability ratio, asset turnover, operating efficiency and company size have a significant impact on the total factor growth rate of Chinese life insurance companies. Among the macro factors, GDP growth rate, inflation rate and unemployment rate have a significant impact on the total factor growth rate of Chinese life insurance companies.
\end{abstract}

Key words: Chinese life insurance company; total factor productivity; Malmquist index; analysis of influencing factors

\section{INTRODUCTION}

In recent years, the rapid development of insurance industry has become a highlight of China's national economic growth. However, China's insurance industry has been pursuing the speed of development unilaterally, neglecting the quality of development and adopting an extensive business model for a long time. Chinese insurance companies are facing more fierce market competition. How to improve the total factor productivity has gradually become the key to the stable operation and sustainable and healthy development of China's insurance industry. Therefore, it is of great practical significance to scientifically evaluate the Total Factor Productivity (TFP) of Chinese life insurance companies and to study its influencing factors.

Total Factor Productivity (TFP) refers to the comprehensive production efficiency of production units (mainly enterprises) as various elements of the system. The efficiency of insurance companies has been concerned by foreign scholars. Early studies mainly focus on the efficiency of insurance companies from the perspective of economies of scale and economies of scope. Segal (2003) used the method of transcendental logarithmic cost function to study the economies of scale and scope of the American life insurance industry. The results showed that the American life insurance industry in general had economies of scale. Cummins et al. (2010) calculated the DEA efficiency of American insurance industry from 1993 to 2006, and found that only the cost efficiency of property insurance industry realized the scope economy. In recent years, many domestic scholars began to pay attention to the efficiency of insurance companies. Huang (2006) used SFA method to calculate the cost efficiency and profit efficiency of 28 Insurance Companies in China from 1999 to 2004. Through empirical research, it was found that changing the property structure of insurance companies could not effectively improve efficiency, but corporate governance structure, asset size and other factors were the main factors affecting the efficiency of China's insurance industry. Xie et al. (2009) took 18 insurance groups in Europe, the United States, Japan and Taiwan as samples to measure their respective operating efficiency. The results showed that the efficiency of comprehensive 
insurance companies, financial holding insurance companies in Japan and Taiwan were the highest. Huang (2012) proposed an improved three-stage DEA model based on the dual perspective of risk and environment. After the adjustment of endogenous risk and exogenous environment, the technical efficiency value of Chinese insurance companies from 1999 to 2009 was calculated. Cui (2015) used Data Envelopment Analysis (DEA) method to calculate the Malmquist productivity index of 33 insurance companies from 2002 to 2012, and compared the total factor productivity of insurance groups and independent insurance companies.

At present, domestic and foreign scholars have done a lot of research on the efficiency of insurance companies, but few scholars have subdivided life insurance and property insurance companies in the research and specifically studied the total factor productivity of Chinese life insurance companies. Although many scholars have done a lot of empirical analysis on the factors affecting the total factor productivity of other financial institutions like banks, there are no scholars in China who have conducted empirical research on the factors affecting the total factor productivity of Chinese life insurance companies.

Based on the data of 17 Chinese-funded insurance companies from 2007 to 2016, this paper uses Malmquist productivity index method of non-parametric DEA model to estimate the total factor productivity of Chinese-funded insurance companies. On this basis, a panel data model is established to analyze the factors affecting total factor productivity. This paper is divided into five parts. The first part is to sort out the relevant domestic and foreign literatures of the insurance company's total factor productivity. The second part is the introduction of the Malmquist productivity index method of the mainstream method of total factor productivity estimation. The third part is the estimation result of the total factor productivity of Chinese life insurance companies. The fourth part is the detailed theoretical analysis of the factors affecting the total factor productivity of Chinese life insurance companies and the establishment of panel data model and regression analysis. The last part is the conclusion of this paper.

\section{Malmquist Index Analysis Model Based on DEA \\ RESEARCH METHODOLOGY DESIGN}

The Malmquist exponential analysis model based on DEA is an effective method to analyze the change of total factor productivity and relative efficiency of Decision Making Units (DMUs). The basic idea of the method for estimating total factor productivity is the distance function of Malmquist (1953) and the multi-input-multiple output efficiency measure of Farrell (1957). The DEA method proposed by Charnes et al. (1978) and the decomposition of technical efficiency (economic efficiency) by Banker et al. (1984) provide a tool for calculating and decomposing Malmquist productivity index in non-parametric form. On this basis, Fare et al. $(1994,1997)$ calculated the distance function involved in Malmquist total factor productivity index in non-parametric form, and decomposed the Malmquist index analysis model. From then on, Malmquist total factor productivity index analysis model based on DEA has become an effective tool for productivity analysis.

In this paper, the total factor productivity of Chinese life insurance companies is estimated by Malmquist exponential model based on DEA method and its decomposition. The reasons for choosing this method are as follows: Firstly, the production achievements of Chinese life insurance companies should be reflected not only in the profits they create, but also in the role played by social capital financing, but it is difficult to find a suitable production function to reflect this characteristic at present; secondly, a large number of Chinese life insurance companies were established after 2006, so it is very difficult to find a suitable production function to reflect this characteristic. The data sequence that can be collected is relatively short, if the parameter estimation method is used, the accuracy of the estimation results is 
difficult to support. Thirdly, the Malmquist index analysis model can not only avoid the previous two problems, but also decompose the total factor productivity, which is conducive to further research and analysis of the reasons for the change of the total factor productivity of Chinese life insurance companies.

\section{Model decomposition of Malmquist exponential analysis}

According to the relevant research of scholars, the Malmquist index based on output angle can be expressed as follows:

$$
\mathrm{M}_{0}^{\mathrm{t}}\left(\mathrm{x}_{\mathrm{t}+1}, \mathrm{y}_{\mathrm{t}+1}, \mathrm{x}_{\mathrm{t}}, \mathrm{y}_{\mathrm{t}}\right)=\mathrm{D}_{0}^{\mathrm{t}}\left(\mathrm{x}_{\mathrm{t}+1}, \mathrm{y}_{\mathrm{t}+1}\right) / \mathrm{D}_{0}^{\mathrm{t}}\left(\mathrm{x}_{\mathrm{t}}, \mathrm{yt}_{\mathrm{t}}\right)
$$

Similarly, with the $t+1$ period technology $T_{t+1}$ as a reference, the Malmquist index based on the output angle can be expressed as:

$$
\mathrm{M}_{0}^{\mathrm{t}+1}\left(\mathrm{x}_{\mathrm{t}+1}, \mathrm{y}_{\mathrm{t}+1}, \mathrm{x}_{\mathrm{t}}, \mathrm{y}_{\mathrm{t}}\right)=\mathrm{D}_{0}^{\mathrm{t}+1}\left(\mathrm{x}_{\mathrm{t}+1}, \mathrm{y}_{\mathrm{t}+1}\right) / \mathrm{D}_{0}^{\mathrm{t}+1}\left(\mathrm{x}_{\mathrm{t}}, \mathrm{y}_{\mathrm{t}}\right)
$$

The Malmquist index, which measures productivity changes from $t$ to $t+1$, is:

$$
\mathrm{M}_{0}^{\mathrm{t}, \mathrm{t}+1}\left(\mathrm{x}_{\mathrm{t}+1}, \mathrm{y}_{\mathrm{t}+1}, \mathrm{x}_{\mathrm{t}}, \mathrm{y}_{\mathrm{t}}\right)=\left[\frac{D_{0}^{t}\left(x_{t+1}, y_{t+1}\right)}{D_{0}^{t}\left(x_{t}, y_{t}\right)} \times \frac{D_{0}^{t+1}\left(x_{t+1}, y_{t+1}\right)}{D_{0}^{t+1}\left(x_{t}, y_{t}\right)}\right]^{\frac{1}{2}}
$$

Where $\left(\mathrm{x}_{\mathrm{t}}, \mathrm{y}_{\mathrm{t}}\right)$ and $\left(\mathrm{x}_{\mathrm{t}+1}, \mathrm{y}_{\mathrm{t}+1}\right)$ represent the input and output vectors of $t$ and $t+1$, respectively; $D_{0}^{t}$ and $D_{0}^{t+1}$ respectively represent the technique of t-time $T^{t}$ is the distance function of the period $t$ and the period $t+1$.

The above-mentioned Malmquist index can be decomposed into a comprehensive technical efficiency change index (TEC) and a technical efficiency improvement index (TCP) under the assumption that the scale returns are constant. Among them, the comprehensive technical efficiency change index (TEC) is the relative technical efficiency change of the decision-making unit from $t$ to $t+1$; the technical efficiency progress index (TCP) is the movement of the optimal efficiency boundary of the decision-making unit from $t$ to $t+1$. . The specific decomposition process is as follows:

$$
\mathrm{M}_{\mathrm{c}}^{\mathrm{t}, \mathrm{t}+1}\left(\mathrm{x}_{\mathrm{t}+1}, \mathrm{y}_{\mathrm{t}+1}, \mathrm{x}_{\mathrm{t}}, \mathrm{y}_{\mathrm{t}}\right)=\frac{D_{c}^{t+1}\left(x_{t+1}, y_{t+1}\right)}{D_{c}^{t}\left(x_{t}, y_{t}\right)} \times\left[\frac{D_{c}^{t}\left(x_{t+1}, y_{t+1}\right)}{D_{c}^{t+1}\left(x_{t}, y_{t} \mid C\right)} \times \frac{D_{c}^{t}\left(x_{t+1}, y_{t+1}\right)}{D_{c}^{t+1}\left(x_{t}, y_{t}\right)}\right]^{\frac{1}{2}}=\mathrm{TEC} \times \mathrm{TCP}
$$

The Integrated Technology Efficiency Change Index (TEC) can be further divided into the Pure Technical Efficiency Change Index (PTEC) and the Scale Efficiency Change Index (SC). The specific decomposition process is as follows:

$$
\mathrm{M}_{\mathrm{v}, \mathrm{C}}^{\mathrm{t}, \mathrm{t}}\left(\mathrm{x}_{\mathrm{t}+1}, \mathrm{y}_{\mathrm{t}+1}, \mathrm{x}_{\mathrm{t}}, \mathrm{y}_{\mathrm{t}}\right)=\frac{D_{v}^{t+1}\left(x_{t+1}, y_{t+1}\right)}{D_{v}^{t}\left(x_{t}, y_{t}\right)} \times\left|\frac{D_{v}^{t}\left(x_{t}, y_{t}\right)}{D_{c}^{t+1}\left(x_{t}, y_{t}\right)} / \frac{D_{v}^{t+1}\left(x_{t+1}, y_{t+1}\right)}{D_{c}^{t+1}\left(x_{t+1}, y_{t+1}\right)}\right|=\mathrm{PTEC} \times \mathrm{SC} \times \mathrm{TCP}
$$

\section{TOTAL FACTOR PRODUCTIVITY ESTIMATION OF CHINESE INSURANCE COMPANIES Sample Selection and Data Source}

This paper selects the 2007-2016 Chinese life insurance company as a sample. After eliminating the Chinese life insurance companies and related companies with less than eight years of establishment, the panel data of 17 Chinese life insurance companies will be obtained as a research sample. The data used in this paper is the balance panel data. The sample period is from 2007 to 2016. All data are from the China Insurance Yearbook (2008-2017) and China 
Statistical Yearbook (2008-2017) and the annual report published on the insurance company website. In this paper, DEAP2.1 software is used to measure the total factor productivity of each company.

The research sample selected in this paper include: a total of 17 Chinese funded life insurance company, including China Life Co., Ltd., Pacific Life Insurance, Taikang Life Insurance, Taiping Life, Xinhua Life Insurance, PICC Life Insurance, Huaixia Life Insurance, Funde Sino Life Insurance, Junkang Life Insurance, Greatwall Life Insurance, Huatai Life Insurance, Yingda Taihe Life Insurance, Union Life Insurance, Xintai Life Insurance, Happy Life Insurance, Minsheng Life Insurance and Guohua Life Insurance.

\section{Selection of Input-Output Variables}

Using DEA-Malmquist index analysis model to calculate the total factor productivity of Chinese life insurance companies, the key problem is to select input and output indicators. Because the production and operation modes of insurance companies are quite different from those of other types of enterprises, it is very important to select input and output indicators when calculating the total factor productivity of Chinese life insurance companies. When calculating the total factor productivity of the financial industry, the selection of input and output indicators can be roughly divided into three methods: user cost method, value-added method and assets (intermediary) method. According to the relevant research of domestic and foreign scholars (Cummins and Weiss, 2000; Cui, 2015), value-added method is the most appropriate method to study the total factor productivity of insurance companies. In this paper, when selecting indicators, combined with the availability of data and the relevance of indicators, we select salary costs, other operating costs and capital as input indicators, and premium income and the use of insurance funds as output indicators.

\section{The selection of input variables}

According to the related research of scholars at home and abroad, the insurance industry investment variables are generally divided into the following three categories: staff salaries, other operating expenses and capital. Staff salaries is an important insurance company investment. In this paper, staff salaries is calculated by multiplying the "average wages of employees in the insurance industry" by "the number of employees of the company". Other operating expenses are material inputs other than employee compensation expenses, and this paper subtracts "employee compensation expenses" from "operating expenses" as other operating expenses of Chinese life insurance companies. Capital is an important index to reflect the Chinese life insurance companies underwriting capacity, this paper refers to "paid-in capital (or equity)" plus "capital reserve" as the total amount of company capital.

\section{The selection of output variables}

In this paper, the premium income is the original premium income of a Chinese life insurance company, that is, the "insurance business income" in the company's profit and loss statement minus the "divided premium income". Income from the use of insurance funds is the income of Chinese life insurance companies make up an important source of underwriting losses and increase the net profit of the company. This paper uses the "income from investment" in the company's income statement plus "exchange earnings" as income from the use of insurance funds of Chinese life insurance companies. Table 1 is the selection of input and output variables and the specific definition of name. 
Table 1

Input-Output Variables and Definitions

\begin{tabular}{|c|c|c|}
\hline & Variables name & Variables definition \\
\hline \multirow{3}{*}{ Input variables } & Staff salaries & $\begin{array}{l}\text { Average Wage of Insurance Workers } \\
\times \text { Number of staff and workers }\end{array}$ \\
\hline & Other operating expenses & Operating expenses-Salary expenses of employees \\
\hline & Capital & Paid in capital(or Equity)+ Capital surplus \\
\hline \multirow[b]{2}{*}{ Output variables } & Premium income & Insurance business income-Sub-Premium income \\
\hline & $\begin{array}{l}\text { Income from the use of insurance } \\
\text { funds }\end{array}$ & Income from investment+ Exchange earnings \\
\hline
\end{tabular}

Note : (1)The definition of the third variable in Table 1 is consistent with the accounting items in the Annual Report of China Insurance Yearbook and the official website of Chinese life insurance companies.

(2)The items of "investment income" in the income statement include "financial assets income measured at fair value and its changes included in current profits and losses", "investment income held to maturity", "bank deposit interest", "loan interest" and "other income".

According to China Insurance Yearbook and China Statistical Yearbook, after considering the availability of relevant data and excluding insurance institutions with negative input and output variables, this paper collects relevant data of Chinese life insurance companies from 2007 to 2016, with a total sample of 170 decision-making units. Table 2 is the descriptive statistics of input and output variables of Chinese life insurance companies during the sample period.

Table 2

Descriptive statistics of input and output variables of Chinese life insurance companies from 2007 to 2016 (unit: million yuan)

\begin{tabular}{llcccc}
\hline & \multicolumn{1}{c}{ Variables } & Mean & $\begin{array}{c}\text { Standard } \\
\text { Deviation }\end{array}$ & Maximum & Minimum \\
\hline \multirow{2}{*}{$\begin{array}{l}\text { Input } \\
\text { variables }\end{array}$} & Salary expenses of employees & 1195.79 & 1913.35 & 11566.26 & 4.75 \\
& Other operating expenses & 49560.56 & 88266.9 & 454150.96 & 0 \\
& Capital fund & 11423.8 & 20118.58 & 125634 & 279 \\
Output & Premium income & 44041.22 & 77995.55 & 430495 & 0 \\
variables & Income from the use of insurance & 11809.42 & 22953.04 & 146355 & 0 \\
\hline
\end{tabular}

Source: 2008-2017 China Insurance Yearbook and China Statistical Yearbook.

\section{Measurement of Total Factor Productivity of Chinese Insurance Companies}

Based on the statistical data of 17 Chinese life insurance companies, according to the Malmquist index analysis of DEA model and using DEAP 2.1 software, this paper calculates the annual average total factor productivity of Chinese life insurance industry from 2008 to 2016. The specific results are shown in Table 3.

Table 3 shows that the total factor productivity of PICC Life Insurance is the highest in the sample listed companies (1.1064), while the total factor productivity of China Life Stock is the lowest (1.0312). In joint-stock companies, the average value of total factor productivity (1.1881) of Chinese life insurance companies is larger than that of state-owned Chinese life insurance companies (1.0550). Greatwall Life Insurance is the company with the highest total factor productivity (1.5489) among 17 Chinese life insurance companies, while Union Life is the company with the lowest total factor productivity $(0.9774)$. The top three companies in 
total factor productivity are Great Wall Life Insurance (1.5489), Guohua Life Insurance (1.3521) and Xintai Life Insurance (1.3061). Through this table, we can find that the main reason for the relatively high total factor productivity of these companies is that their technical efficiency progress index is higher.

Table 3

Changes and Decomposition of the Annual Mean Malmquist Index of Chinese Life Insurance Industry from 2008 to 2016

\begin{tabular}{lccccc}
\hline \multicolumn{1}{c}{ Corporate Name } & $\begin{array}{c}\text { Comprehensive } \\
\text { Technical Efficiency } \\
\text { Change Index } \\
\text { (TEC) }\end{array}$ & $\begin{array}{c}\text { Technical } \\
\text { Efficiency } \\
\text { Progress Index } \\
\text { (TCP) }\end{array}$ & $\begin{array}{c}\text { Pure Technical } \\
\text { Efficiency } \\
\text { Change Index } \\
\text { (PTEC) }\end{array}$ & $\begin{array}{c}\text { Scale } \\
\text { Efficiency } \\
\text { Change } \\
\text { Index (SC) }\end{array}$ & $\begin{array}{c}\text { Total Factor } \\
\text { Productivity } \\
\text { Index } \\
\text { (TFP) }\end{array}$ \\
\hline China Life Co., Ltd. & 0.9850 & 1.0493 & 1.0000 & 0.9850 & 1.0312 \\
Pacific Life & 0.9897 & 1.0873 & 0.9992 & 0.9906 & 1.0919 \\
Taikang Life & 1.0000 & 1.2061 & 1.0000 & 1.0000 & 1.2061 \\
Taiping Life & 1.0038 & 1.0492 & 1.0003 & 0.9993 & 1.0419 \\
Xinhua Life & 0.9898 & 1.1126 & 0.9946 & 0.9950 & 1.1022 \\
PICC Life & 1.0006 & 1.1052 & 1.0002 & 1.0002 & 1.1064 \\
Huaxia Life & 1.1076 & 1.1640 & 1.0671 & 1.0279 & 1.2022 \\
Funde Sino Life & 1.0328 & 1.1189 & 1.0080 & 1.0111 & 1.0643 \\
Junkang Life & 1.0009 & 1.2406 & 1.0000 & 1.0009 & 1.2541 \\
Greatwall Life & 1.0057 & 1.5691 & 1.0024 & 0.9991 & 1.5489 \\
Huatai life & 1.1166 & 1.1766 & 1.0388 & 1.0233 & 1.1252 \\
Yingda Taihe Life & 1.0980 & 1.1839 & 1.0154 & 1.0622 & 1.1799 \\
Union Life & 1.0000 & 0.9774 & 1.0000 & 1.0000 & 0.9774 \\
Xintai Life & 1.0000 & 1.3061 & 1.0000 & 1.0000 & 1.3061 \\
Happy Life & 1.0000 & 1.1097 & 1.0000 & 1.0000 & 1.1097 \\
Minsheng Life & 1.0842 & 1.1713 & 1.0673 & 1.0039 & 1.0990 \\
Guohua Life & 1.0000 & 1.3521 & 1.0000 & 1.0000 & 1.3521 \\
Mean Value & 1.0244 & 1.1753 & 1.0114 & 1.0058 & 1.1646 \\
\hline
\end{tabular}

Source: The results in the figure are calculated by using DEAP2.1 software.

Table 4 shows the change and decomposition of average total factor productivity of 17 Chinese life insurance companies from 2008 to 2016. From the data of time series, the average total factor productivity of 17 Chinese life insurance companies in 2008-2016 is 1.1646, which shows a trend of decreasing first and then increasing. From 2008 to 2012, the average value of total factor productivity showed a downward trend, which was due to the obvious decline of the index of technological efficiency progress. From 2012 to 2016, the average of total factor productivity has increased significantly, because at this stage, the index of technological efficiency progress has been significantly improved. Totally speaking, the average value of the comprehensive index of technological efficiency change and the index of technological efficiency progress in the study period are both greater than 1, indicating that both indexes contributed to the improvement of the average value of total factor growth rate during the study period. 
Table 4

Changes and Decomposition of Malmquist Index of 17 Chinese Life Insurance Companies in 2008-2016

\begin{tabular}{cccccc}
\hline Year & $\begin{array}{c}\text { Comprehensive } \\
\text { Technical Efficiency } \\
\text { Change Index } \\
\text { (TEC) }\end{array}$ & $\begin{array}{c}\text { Technical } \\
\text { Efficiency } \\
\text { Progress } \\
\text { Index (TCP) }\end{array}$ & $\begin{array}{c}\text { Pure Technical } \\
\text { Efficiency Change } \\
\text { Index } \\
\text { (PTEC) }\end{array}$ & $\begin{array}{c}\text { Scale } \\
\text { Efficiency } \\
\text { Change } \\
\text { Index (SC) }\end{array}$ & $\begin{array}{c}\text { Total Factor } \\
\text { Productivity } \\
\text { Index } \\
\text { (TFP) }\end{array}$ \\
\hline 2008 & 1.0138 & 1.2524 & 1.0035 & 1.0091 & 1.2698 \\
2009 & 0.8644 & 1.6108 & 0.8963 & 0.9598 & 1.4128 \\
2010 & 1.2377 & 0.8776 & 1.1668 & 1.0474 & 1.0134 \\
2011 & 0.9535 & 1.1753 & 0.9674 & 0.9847 & 1.1281 \\
2012 & 0.9554 & 0.9350 & 0.9931 & 0.9626 & 0.8932 \\
2013 & 1.1602 & 0.9581 & 1.0548 & 1.0985 & 1.0803 \\
2014 & 0.9112 & 1.3759 & 0.9470 & 0.9553 & 1.2290 \\
2015 & 1.1555 & 1.0115 & 1.0863 & 1.0549 & 1.1194 \\
2016 & 0.9677 & 1.3807 & 0.9874 & 0.9798 & 1.3356 \\
Mean value & 1.0244 & 1.1753 & 1.0114 & 1.0058 & 1.1646 \\
\hline
\end{tabular}

Source: The results in the table are calculated by using DEAP2.1 software.

\section{ANALYSIS ON THE INFLUENCING FACTORS OF TOTAL FACTOR PRODUCTIVITY OF CHINESE INSURANCE COMPANIES}

\section{Influencing factors and definitions of variables}

In calculating the total factor productivity of Chinese life insurance companies, we should not only evaluate the total factor productivity of 17 Chinese life insurance companies, but also analyze the main factors affecting the total factor productivity of Chinese life insurance companies, so as to urge Chinese life insurance companies to pay attention to these factors in the future and continuously improve the total factor productivity of Chinese life insurance companies. This paper will analyze the factors affecting the total factor productivity of Chinese life insurance companies from micro and macro factors, combining the existing research on the total factor productivity of financial institutions and the actual operating characteristics of insurance companies in China.

According to the relevant studies of Berger and Mester (1997), Zheng and Cao (2005), Yuan and Zhang (2009), domestic and foreign scholars show that the micro-internal factors affecting total factor productivity of financial institutions mainly include asset-liability ratio, asset turnover ratio, corporate operating efficiency, corporate internal governance and corporate size. According to the research done by Wang and Tan (2007), Yuan and Zhang (2009), it is shown that macro-external factors such as GDP growth rate, growth rate of money supply, inflation rate and unemployment rate will all affect the total factor productivity of financial institutions. Two points need to be explained here are that the indicator of agency cost is not inversely proportional to the internal management of the company. The higher the value of the indicator, the higher the agency cost of the company and the less satisfactory the internal governance of the company. The impact of inflation on macro-economy will be delayed for about one year, so the inflation rate is selected from the data of the previous year. The relevant variables and their definitions are shown in Table 5 below. 
Table 5

Relevant Variables and Definitions

\begin{tabular}{|c|c|c|c|}
\hline & Variables & $\begin{array}{l}\text { Variable } \\
\text { Symbols }\end{array}$ & Variable Definitions \\
\hline \multirow{5}{*}{ Micro factor } & Asset-liability ratio & DB & Year-end total liabilities / Year-end total assets \\
\hline & Asset turnover rate & AT & Year-end operating income/Year-end total assets \\
\hline & Company operating efficiency & INC & $\begin{array}{l}\text { Year-end premium income/Year-end operating } \\
\text { income }\end{array}$ \\
\hline & $\begin{array}{l}\text { Corporate internal } \\
\text { governance }\end{array}$ & GOV & $\begin{array}{l}\text { Year-end out-of-business expenditure/Year-end } \\
\text { total revenue }\end{array}$ \\
\hline & Company size & SIZE & Logarithm of year-end total assets \\
\hline \multirow{4}{*}{ Macro factor } & GDP growth rate & GDP & Domestic GDP growth rate in that year \\
\hline & Growth rate of money supply & M2 & $\begin{array}{l}\text { The growth rate of domestic money supply in that } \\
\text { year }\end{array}$ \\
\hline & Inflation rate & FA & Domestic inflation rate in the previous year \\
\hline & Unemployment rate & UE & $\begin{array}{l}\text { The registered unemployment rate of domestic } \\
\text { cities and } \\
\text { towns in that year }\end{array}$ \\
\hline
\end{tabular}

Note: Total income is (business income + non-business income).

Table 6 shows descriptive statistics of micro and macro factors. From this table, we can see that among the micro factors, the average asset-liability ratio of Chinese life insurance companies is higher, reaching $90.5 \%$; the average asset turnover ratio is 0.289 , indicating that the assets turnover rate of Chinese life insurance companies is general; the average operating efficiency of the companies reaches $94.4 \%$, indicating that the main business income of Chinese life insurance companies comes from premium income. Among the macro factors, the average GDP growth rate is $9 \%$, which indicates that the GDP growth rate of our country is higher during the study period; the average growth rate of money supply is $31.9 \%$, which indicates that the money supply of our country is on the increase trend as a whole during the study period; the average of inflation rate and unemployment rate are smaller.

Table 6

Descriptive statistics of micro and macro factors

\begin{tabular}{llccccc}
\hline \multirow{2}{*}{ Variables } & Variable & Mean & Standard & Maximum & Minimum \\
& Seviation & Value & Value \\
\hline \multirow{5}{*}{ Micro factors } & Syset-liability ratio & DB & 0.905 & 0.065 & 1 & 0 \\
& Asset turnover rate & AT & 0.289 & 0.178 & 1.019 & 0 \\
& Company operating efficiency & INC & 0.944 & 0.949 & 1 & 0 \\
& Corporate internal governance & GOV & 0.001 & 0.002 & 0.021 & 0 \\
& Company size & SIZE & 9.548 & 1.947 & 13.217 & 0 \\
& GDP growth rate of China & GDP & 0.090 & 0.023 & 0.142 & 0.067 \\
Macro factors & Growth rate of money supply of & M2 & 0.319 & 0.079 & 0.5 & 0.2 \\
& China & FA & 0.027 & 0.020 & 0.059 & -0.007 \\
& Inflation rate of China & UE & 0.041 & 0.001 & 0.043 & 0.04 \\
\hline
\end{tabular}

Note: The specific values of micro-factor variables come from China Insurance Yearbook 2008-2017. The specific values of macro-factor variables are queried through the official website of the National Bureau of Statistics.

\section{Analysis of Micro-factors Affecting Total Factor Productivity}

Based on the above analysis, this paper will establish a fixed effect model of panel data for regression analysis. This paper takes total factor productivity (TFP) as the explanatory 
variable, and five micro-internal variables, including asset-liability ratio (DB), asset turnover rate (AT), company operating efficiency (INC), company internal governance (GOV) and company size (SIZE), as explanatory variables, to construct panel data model. Panel data models are generally divided into three types: fixed-effect regression, random-effect regression and mixed-effect regression. After F-test and Hausman test, this paper will choose a fixed-effect regression model, which is shown by the following formula (1):

$$
T F P_{i t}=\alpha+\beta_{1} \times D B_{i t}+\beta_{2} \times A T_{i t}+\beta_{3} \times I N C_{i t}+\beta_{4} \times G O V_{i t}+\beta_{5} \times S I Z E_{i t}+\varepsilon_{i t}
$$

Among them, TFP it is the total factor productivity value of the first Chinese life insurance company in the $t$ year, $i=1,2, \ldots, 17, t=2008,2009, \ldots, 2016$. DB, AT, INC, GOV and SIZE represent the explanatory variables respectively; $\alpha$ and $\beta_{\mathrm{i}}$ are the parameters to be estimated for each explanatory variable; $\varepsilon_{\mathrm{it}}$ is the random error term.

Table 7

Coefficient Matrix of Micro-variables

\begin{tabular}{cccccc}
\hline & DB & AT & INC & GOV & SIZE \\
\hline DB & 1 & -0.2221 & 0.0902 & -0.0176 & 0.1085 \\
AT & -0.2221 & 1 & -0.1524 & -0.0055 & -0.0032 \\
INC & 0.0902 & -0.1524 & 1 & 0.2203 & -0.2187 \\
GOV & -0.0176 & -0.0055 & 0.2203 & 1 & -0.0831 \\
SIZE & 0.1085 & -0.0032 & -0.2187 & -0.0831 & 1 \\
\hline
\end{tabular}

Table 7 provides the correlation coefficients among the micro-explanatory variables. From this table, it can be seen that the correlation among the explanatory variables is relatively small, so the multiple collinearity problem of regression results can be avoided to a great extent. The correlation coefficient matrix can only explain the possible correlations among the main variables, and further empirical tests of the variables need to be carried out through the panel data model. In this paper, the software STATA13.0 will be used to regression model 1 . The specific regression results are shown in Table 8 below.

The empirical results show that the asset-liability ratio (DB) is positively correlated with the total factor productivity of Chinese life insurance companies, which indicates that the high proportion of the company's own capital does not necessarily help Chinese life insurance companies to improve the total factor productivity. Asset turnover rate (AT) is an important index to measure the efficiency of corporate asset management, and it has a significant positive correlation with the total factor productivity of Chinese life insurance companies. It shows that the improvement of asset turnover rate of Chinese life insurance companies can help improve the total factor productivity of companies. The operating efficiency (INC) of the company is positively correlated with the total factor productivity of the Chinese life insurance company, and is significant at the level of $1 \%$. This shows that the increase of the proportion of the main operating income to the operating income of the company contributes to the improvement of the total factor productivity of the Chinese life insurance company. Internal governance (GOV) is positively correlated with total factor productivity of Chinese life insurance companies, but the effect is not significant. The regression coefficient of company size (SIZE) is 0.1423 , which is significant at the level of $5 \%$. This shows that moderate expansion of company size can help Chinese life insurance companies to improve total factor productivity, which is also consistent with the conclusions of most scholars. 
Table 8

The regression results of micro-factors influencing total Factor productivity of Chinese life insurance companies

\begin{tabular}{ccc}
\hline Variable & $\begin{array}{c}\text { Regression } \\
\text { Coefficient }\end{array}$ & $\begin{array}{c}\text { t-test } \\
\text { Value }\end{array}$ \\
\hline DB & 1.6086 & $1.94^{*}$ \\
AT & 1.0563 & $3.66^{* * *}$ \\
INC & 0.2925 & $5.22^{* * *}$ \\
GOV & 5.3186 & 0.22 \\
SIZE & 0.1423 & $2.53^{* *}$ \\
cons & -2.2368 & -2.31 \\
Adjusted-R & \multicolumn{2}{c}{0.2187} \\
F-statistics & \multicolumn{2}{c}{$7.95^{* * *}$} \\
Sample Size & \multicolumn{2}{c}{153} \\
\hline
\end{tabular}

Note: $* * *, * *, *$ respectively indicate the significance level test of $1 \%, 5 \%$ and $10 \%$, with T statistics in parentheses.

\section{Analysis of Macro-factors Affecting Total Factor Productivity}

Since the above macroeconomic factors are the main indicators to measure the economic cycle and reflect the external economic environment faced by Chinese life insurance companies, there may be multiple collinearity problems between them. Therefore, it is necessary to analyze the degree of correlation among macroeconomic variables. Table 9 shows that although the correlation between GDP growth rate of China (GDP) and money supply growth rate of China (M2) is -0.5421 , the correlation coefficient between GDP growth rate of China (GDP) and unemployment rate of China (UE) is 0.5066, they are not significant. The correlation coefficients of other macro variables are lower than 0.5 .

Table 9

Coefficient Matrix of Relevance among Macro Variables

\begin{tabular}{ccccc}
\hline & GDP & M2 & FA & UE \\
\hline \multirow{2}{*}{ GDP } & 1 & -0.5421 & 0.4046 & 0.5066 \\
& & $(0.1316)$ & $(0.2800)$ & $(0.1639)$ \\
M2 & -0.5421 & 1 & -0.4083 & -0.0079 \\
& $(0.1316)$ & & $(0.2753)$ & $(0.9839)$ \\
FA & 0.4046 & -0.4083 & 1 & -0.3607 \\
& $(0.2800)$ & $(0.2753)$ & & $(0.3403)$ \\
UE & 0.5066 & -0.0079 & -0.3607 & 1 \\
& $(0.1639)$ & $(0.9839)$ & $(0.3403)$ & \\
\hline
\end{tabular}

Note: The number in parentheses is $\mathrm{P}$-value.

In order to further explore the specific impact degree and direction of macroeconomic indicators on total factor productivity of Chinese life insurance companies, this paper establishes the following model (2) and uses OLS least squares method and STATA 13.0 to regression the model. The specific regression results are shown in Table 10.

$$
T F P=\alpha+\beta_{1} \times G D P+\beta_{2} \times M 2+\beta_{3} \times F A+\beta_{4} \times U E+\varepsilon
$$

Among them, TFP is the total factor productivity value of Chinese life insurance companies; GDP represents the GDP growth rate of China, M2 represents money supply growth rate of China, FA represents inflation rate of China, UE represents unemployment rate of China; $\alpha$ and $\beta$ are all parameters to be estimated for each explanatory variable; $\varepsilon$ is random error term. 
Table 10

Regression results of macro-influence factors of total factor productivity of Chinese life insurance companies

\begin{tabular}{ccc}
\hline & Regression Coefficient & t-test Value \\
\hline GDP & 15.323 & $2.41^{*}$ \\
M2 & 1.0339 & 1.39 \\
FA & -8.8623 & $-2.52^{*}$ \\
UE & -240.9921 & $-2.63^{*}$ \\
cons & 9.7069 & $2.86^{*}$ \\
R-squared & 0.6867 & \\
F-statistics & 2.19 & \\
\hline
\end{tabular}

Note: $* * *, * *, *$ respectively indicate the significance level test of $1 \%, 5 \%$ and $10 \%$, with $\mathrm{T}$ statistics in parentheses.

From the above regression results, we can see that GDP growth rate of China (GDP) has a significant positive role in promoting the growth rate of total factor of Chinese life insurance companies, indicating that there is a clear relationship between them. The growth rate of money supply of China (M2) also has no significant positive effect on the growth rate of total factor of Chinese capital. The regression coefficient of the inflation rate of China (FA) in the table is - 8.8623, which is significant at the level of $1 \%$. It shows that the inflation rate has a negative correlation with the total factor productivity of Chinese life insurance companies during the study period. The unemployment rate of China (UE) has a negative effect on the total factor productivity of Chinese-funded life insurance companies, and is significant at the level of $1 \%$. This shows that the increase of unemployment rate has a significant negative effect on the total factor productivity of Chinese-funded life insurance companies.

\section{CONCLUSIONS}

Based on the panel data of 17 Chinese life insurance companies from 2007 to 2016 and Malmquist exponential analysis method based on non-parametric DEA model, this paper calculates the total factor productivity of Chinese life insurance companies and takes the total factor productivity value as the explanatory variable to construct a panel data model, so as to explore the micro and macro factors that affect the total factor productivity of Chinese life insurance companies. The empirical results show that among the micro-internal factors, assetliability ratio, asset turnover ratio, company operating efficiency and company size have significant effects on the total factor growth rate of Chinese-funded life insurance companies; among the macro-external factors, GDP growth rate, inflation rate and unemployment rate have significant effects on the total factor growth rate of Chinese-funded life insurance companies.

Based on the above empirical analysis results, this paper puts forward the following suggestions on how to further improve the total factor productivity of Chinese life insurance companies. From the micro point of view, Chinese life insurance companies should start from asset turnover, company operating efficiency and company size to improve the total factor productivity of the company. Firstly, we should improve the operating efficiency of Chinese life insurance companies and increase the proportion of business income in total income. In recent years, China's financial industry has opened its doors to the world, and more and more foreign insurance companies have flooded into the Chinese market, bringing unprecedented challenges to Chinese insurance companies. Therefore, in the fierce market environment, Chinese life insurance companies should pay more attention to the main business income and improve the total factor productivity of Chinese life insurance companies by increasing the proportion of premium income in business income. Secondly, Chinese-funded life insurance 
companies should continuously improve the turnover rate of assets, so as to help improve the total factor productivity of the company. In addition, Chinese-funded life insurance companies should appropriately expand the size of the company, continuously increase market share and further help Chinese-funded companies to improve total factor productivity. The main conclusion of the macroeconomic factor model is that the total factor productivity of Chinese life insurance companies is significantly affected by GDP growth rate, inflation rate and unemployment rate. GDP has a positive impact on Chinese-funded life insurance companies, and the effect is very significant, indicating that most Chinese-funded life insurance companies have economies of scope. Therefore, the scope of business of Chinese life insurance companies should be appropriately expanded, and Chinese life insurance companies should be allowed to conduct appropriate mixed operation, increase investment and other businesses. Without violating laws and regulations, they should cooperate with banks, securities and other financial institutions, so as to achieve the goal of improving the total factor productivity of Chinese life insurance companies in an all-round way.

\section{References:}

Banker , R.D., A.Charnes and W.W. Cooper., 1984, Some Models for Estimating Technical and Scale Inefficiencies in Data Envelopment Analysis. Management Science Vol.30(9), 1078-1092.

Berger, A.N., Mester L.J., 1997. Inside the Black Box: What Explains Differences in the Efficiencies of Financial Institution ?. Journal of Banking and Finance , Vol.21 , pp895-947.

Charnes, A., W.W.Cooper and E. Rhodes, 1978. Measuring the Efficiency of Decision Making Units. European Journal of Operational Research , 429-444.

Cummins, D , M. Weiss, 2000. Analyzing Firm Performance in the Insurance Industry Using Frontier Efficiency Methods, in Georges Dionne (ed.), Handbook of Insurance Economics. Boston: Kluwer Academic Publishers.

Cummins, J., M. Weissand, X. Xie, H.Zi, 2010. Economics of Scope in Financial Services: A DEA Efficiency Analysis of the US Insurance Industry. Journal of Banking and Finance, 34, 1525-1539.

Cui H.X., 2015. Research on Total Factor Productivity of China's Insurance Industry-Based on Comparison between Insurance Group and Independent Insurance Company. Financial Review 1, 100-126.

Fare , Rolf , Shawna Grosskoft, Mary Norris and Zhongyang Zhang, 1994. Productivity Growth, Technical Progress, and Efficiency Change in Industrialized Countries. Economic Review Vol.84(1), 66-83.

Fare, Rolf , Shawna Grosskoft, Mary Norris, 1997. Productivity Growth, Technical Progress, and Efficiency Change in Industrialized Countries: Reply. American Economic Review Vol.87(5):1040-1044.

Farrell, M.J., 1957. The Measurement of Productive Efficiency. Journal of the Royal Statistical Society, Series A (General) Vol.120(3), 253-290.

Huang, W., 2006. An Empirical Study on the Efficiency of Chinese Insurance Institutions Based on SFA Method. Nankai Economic Research 5, 104-115.

Huang, W., 2012. Environment, Risk and Enterprise Technology Efficiency Based on Improved DEA Three-Phase Model. Systems Engineering - Theory \& Practice, 1, 1-10.

Malmquist, Stern, 1953. Index Numbers and Indifference Curves. Trabajos de Estatistica 4(1), 209-242.

Segal, D. A., 2003. Multi-Product Cost Study of the U.S. Life Insurance Industry. Review of Quantitative Finance and Accounting, 20:169-186.

Wang, C., Tan, ZH.X., 2007. Research on the Efficiency Structure of China's Commercial Banks. Economic Research 7, 110-123.

Xie, Q., Chen, Y., Jiang. SH.ZH., 2009. A Comparative Analysis of the Impact of Integrated Management on Insurance Business Efficiency - Experience from Europe, America, Japan and Taiwan. Journal of Finance and Economics 1, 62-67.

Yuan X.L., Zhang, B.SH., 2009. Study on the Factors Affecting the Total Factor Productivity of China's Commercial Banks-A Malmquist Index Analysis Based on DEA Model. The Journal of Quantitative and Technical Economics 4, 93-104. 
Sun, Z. (2020). Research on the Factors Affecting the Total Factor Productivity of Chinese Life Insurance Companies. Archives of Business Research, $8(1), 38-50$.

Zheng, L.J., Cao, T.Q., 2005. An Empirical Analysis of the Efficiency of China's Commercial Banks and its Influencing Factors. Financial Research 1, 91-101. 